UDC 616.36-006.6-085.849

DOI: $10.32345 /$ USMYJ.2(116).2020.33-43

\title{
Левченко Людмила
}

Аспірант кафедри загальної хірургії №1, НМУ імені О.О. Богомольця, Україна

Козачук Єлизавета

Асистент кафедри загальної хірургії №1, НМУ імені О.О. Богомольця, Україна

Земсков Сергій

Д.мед.н., професор кафедри загальної хірургії № 1, НМУ імені О.О. Богомольця, Україна

\section{ЗАСТОСУВАННЯ ПЕРКУТАННОЇ ХІМІЧНОЇ АБЛЯЦІЇ В ЛІКУВАННІ ПАЦІЄНТІВ 3 ГЕПАТОЦЕЛЮЛЯРНОЮ КАРЦИНОМОЮ}

\begin{abstract}
Анотація. Щороку частота виявлення ГЦК невпинно зростає. У період з 1990 по 2015 рік показник вперше діагностованих випадків ГЦК збільшився на 75\%. В Украӥні за 2018 рік спеціальним лікуванням охоплено лище 18,0\% первинних хворих: тільки хірургічним лікуванням4,9\%, комбінованим та комплексним лікуванням - 2,0\%. Незадовільні результати з охоплення спеціальним лікування пов'язані з особливостями етіопатогенезу ГЦК, асимптоматичним перебігом та недосконалою системою скринінгу пацієнтів групи ризику, що утруднює діагностику захворювання на ранніх стадіях. Вибір тактики лікування ГЦК асоиійованою з вірусним гепатитом і цирозом печінки досі залишається складною клінічною проблемою, оскільки "застосування радикального лікування на ранній стадії є наріжним каменем для покращення загальної виживаності таких пацієнтів. Пачієнтам з ГЦК на ранніх стадіях з изирозом печінки, що не підлягають радикальному хірургічному лікуванню на момент звернення, показано застосування методів перкутанної аблячії - радіочастотна абляція, хімічна абляція, кріоабляція, мікрохвильова абляція тощо. Основними показаннями для застосування локальної абляції в лікуванні ГЦК - дуже рання та рання стадія (за BCLC - стадія 0 та A), компенсована або субкомпенсована функція печінки при цирозі (Child - Pugh клас A та B), загальносоматичний статус за ECOG 0-1, діаметр пухлинного вогнища до 5,0 см (найбільш оптимально до 3,0 см), вогнищеве вузлове ураження, солітарне або множинне ураження. Перкутанну абляцію застосовують у якості "брідж"-терапії з метою локального контролю пухлинного росту у пацієнтів, щзо відповідають Міланським критеріям, критеріям UСSFC і знаходяться в списку очікування на трансплантацію. Також дані методи показали свою ефективність як неоад'ювантна “downstaging"-терапія у хворих, що не відповідають критеріям для трансплантації печінки та/або з первинно нерезектабельним ураженням. Протягом багатьох десятиліть перкутанна хімічна абляція була "золотим" стандартом мініінвазивного лікування ГЦК. Даний метод простий у виконанні, не потребує спеціального обладнання, добре переноситься пацієнтами, безпечний та економічно вигідний. Основні хімічні агенти - етанол та оитова кислота. Процедура перкутанної хімічної абляиії передбачає інтратуморальне введення хімічного агенту "real-time" під контролем методів візуалізацї (УЗД або КТ). Хімічна абляція - ие метод другої лінії і застосовується тише у випадках, наявності протипоказань до виконання радіочастотної абляції. Даний метод не супроводжується тяжкими специфбіними ускладненнями та летальністю. Ефективність їі клінічного застосування безпосередньо залежить від розміру пухлинного вогнища. Оптимальний розмір пухлинного вогнища становить не більще 3,0 см. Інтратуморальне введення етанолу призводить до некротизації 90\% -100\% пухлинних вузлів ГЦК діаметром $\leq 2,0$ см та 70\% при пухлинах 2,0 - 3,0 см.
\end{abstract}

Ключові слова: гепатоцелюлярна карцинома, перкутанна абляція пухлин, хімічна абляція, етанол, оцтова кислота.

Cite as: Levchenko L., Kozachuk Ye., Zemskov S. The percutaneous chemical ablation application in the treatment of patients with hepatocellular carcinoma

Ukrainian scientific medical youth journal, issue 2(116), 2020

DOI: $10.32345 /$ USMYJ.2(116).2020.33-43 
Вступ. Близько 90\% від первинного раку печінки становить гепатоцеллюлярна карцинома (ГЦК) (European Association For The Study Of The Liver [EASL], 2018). У світі ГЦК посідає шосте місце в структурі онкозахворюваності (9,3 на 100 тис.) та друге як причина смертності (8,5 на 100 тис.) від злоякісних новоутворень (Ferlay, et al., 2018). Щороку частота виявлення ГЦК невпинно зростає. У період з 1990 по 2015 рік показник вперше діагностованих випадків ГЦК збільшився на $75 \%$, в основному за рахунок зміни вікової структури і зростання населення (EASL, 2018; Akinyemiju, et al., 2017). За даними ВОО3 у 2018 році було зареєстровано 841080 нових випадків ГЦК, померло - 781631 пацєнтів. Переважна частина хворих становила чоловіки 13,9 на 100 тис., жінки - 4,9 на 100 тис. населення (Ferlay, et al., 2018).

Відповідно до уточненої інформації Національного канцер-реєстру України в 2018 році захворюваність на рак печінки відповідала 4,1 на 100 тис., смертність - 3,0 на 100 тис. населення. Не прожили 1-го року 69,0 \% пацієнтів з числа вперше виявлених в 2018 році. Спеціальним лікуванням охоплено лише 18,0\% первинних хворих: тільки хірургічним лікуванням - 4,9\%, комбінованим та комплексним лікуванням - 2,0 \% (Федоренко, та ін., 2020).

Незадовільні результати з охоплення спеціальним лікування пов'язані з особливостями етіопатогенезу ГЦК, асимптоматичним перебігом та недосконалою системою скринінгу пацієнтів групи ризику, що утруднює діагностику захворювання на ранніх стадіях.

Розвиток гепатоцелюлярної карциноми тісно пов'язаний з наявністю хронічного захворювання печінки (цироз печінки, вірусний гепатит В та С, зловживання алкоголю), яке значно знижує функціональні резерви паренхіми печінки та обмежує можливості радикального лікування (EASL, 2018; Akinyemiju, et al., 2017 ).

Загальна 5-річна виживаність хворих на ГЦК становить лише 10 - 15\%, що, в основному, пояснюється діагностикою пухлини на пізніх стадіях (Nault, et al., 2018).

Вибір тактики лікування ГЦК асоційованою 3 вірусним гепатитом і цирозом печінки досі залишається складною клінічною про- блемою, оскільки “застосування радикального лікування на ранній стадії $є$ наріжним каменем для покращення загальної виживаності таких пацієнтів" (Nault, et al., 2018).

Основними методами лікування, що дозволяють досягнути 5-річної виживаності пацієнтів з ГЦК на ранніх стадіях, є резекція, трансплантація та перкутанна абляція (Forner, Reig, \& Bruix, 2018).

Лише у 20\% пацієнтів з ГЦК та цирозом печінки можливо виконати резекцію печінки. Приблизно у половини з них розвивається рецидив протягом 2 років після резекції, а впродовж наступних 5 років частота рецидивування зростає до 70\% - 85\% (Shiina, et al., 2018; Kuang, et al., 2009). Трансплантація печінки $\epsilon$ найбільш оптимальним методом радикального хірургічного лікування таких пацієнтів, оскільки дозволяє ліквідувати обидві клінічні проблеми - ГЦК та цироз печінки (Shiina, et al., 2018). Однак, на даний час, в Україні можливості його застосування значно обмежені.

Пацієнтам з ГЦК на ранніх стадіях $з$ цирозом печінки, що не підлягають радикальному хірургічному лікуванню на момент звернення, показано застосування методів перкутанної абляції (ПА) - радіочастотна абляція, хімічна абляція, кріоабляція, мікрохвильова абляція тощо.

Основними показаннями для застосування ПА в лікуванні ГЦК - дуже рання та рання стадія (за BCLC - стадія 0 та A), компенсована або субкомпенсована функція печінки при циpoзi (Child - Pugh клас A та B), загальносоматичний статус за ECOG 0-1, діаметр пухлинного вогнища до 5,0 см (найбільш оптимально до 3,0 см), вогнищеве вузлове ураження, солітарне або множинне ураження (Thandassery, Goenka, \& Goenka, 2014). Перкутанну абляцію застосовують у якості “брідж”-терапії 3 метою локального контролю пухлинного росту у пацієнтів, що відповідають Міланським критеріям, критеріям University of California San Francisco criteria (UCSFC) і знаходяться в списку очікування на трансплантацію. Також дані методи показали свою ефективність як неоад'ювантна “downstaging”-терапія у хворих, що не відповідають критеріям для трансплантації печінки та/або з первинно нерезектабельним ураженням (Cescon, et al., 2013) 
Протипоказаннями до виконання ПА є: судинна інвазія, наявність позапечінкових віддалених метастазів, сепсис, кахексія, декомпенсована печінкова недостатність та нерегульована коагулопатія. Субкапсулярна локалізація новоутворень, близьке розташування до жовчного міхура та діафрагми асоціюються з підвищеним ризиком виникнення тяжких ускладнень (Tan, Low, \& Thng, 2011; Thandassery, et al., 2014).

У даній статті ми розглянемо особливості застосування перкутанної хімічної абляції (ПХА) в лікуванні пацієнтів з ГЦК на фоні цирозу печінки.

Мета дослідження - узагальнити сучасні тенденції застосування перкутанної хімічної абляції в лікуванні пацієнтів з ГЦК на фоні цирозу печінки.

\section{Матеріали і методи}

Нами було використано пошукові системи: Google Scholar, PubMed, Cochrane Library. Термін публікації статей 2009-2019 рр. Пошук здійснювали за ключовими словами: гепатоцелюлярна карцинома, перкутанна хімічна абляція, перкутанна ін'єкція етанолу, перкутанна ін'єкція оцтової кислоти. Відібрано англомовні та україномовні статті.

\section{Результати}

Протягом багатьох десятиліть ПХА була “золотим" стандартом мініінвазивного лікування ГЦК. Даний метод простий у виконанні, не потребує спеціального обладнання, добре переноситься пацієнтами, безпечний та економічно вигідний. Найбільш часто 3 метою хімічної абляції ГЦК застосовують інтратуморальні ін'єкції 95\% етанолу. Уперше, методику черезшкірного введення етанолу описав Sugiura, у 1983 році. (Sugiura, 1983 as cited in Shiina, et al.,2018). Також використовують $50 \%$ оцтову кислоту, гідроксид натрію та $10 \%$ розчин кальцію хлориду (Dronov, Kovalska, Kozachuk, et al., 2019; Dronov, Kovalska, et al. 2019; Yu, H., \& Burke, 2014;).

\section{Механізми цитодеструкції}

Основний механізм деструктивного впливу етанолу - індукція коагуляційного некрозу, шляхом клітинної дегідратації, денатурації білків пухлинних клітин та судинного тромбозу (Ziemlewicz, et al., 2016).
Задля досягнення цитодеструктивного ефекту хімічний агент повинен потрапити з навколоклітинної рідини в цитоплазму клітини-мішені. Існує два механізми внутрішньоклітинного транспорту пошкоджуючого фактору - дифузія та конвекція. Етанол та оцтова кислота належать до низькомолекулярних сполук, тому їх транспортування відбувається переважно шляхом дифузії за градієнтом концентрації (Yu, H., \& Burke, 2014).

Наявність внутрішньопухлинних перетинок перешкоджає гомогенному інтратуморальному розподілу етанолу, оскільки етанол не здатен проникати через них. У зв'язку з чим для досягнення тотального некрозу новоутворення слід проводити багаторазові ін'єкції у різні дні. Це обмежує його застосування при пухлинних вогнищах більше 3,0 см (Yu, H., \& Burke, 2014).

На відміну від етанолу, оцтова кислота має властивості розчиняти ліпіди і проникати в перетинки та капсули пухлини (Ohnishi, et al., 1994 as cited in Yu, H., \& Burke, 2014). Тому для досягнення еквівалентного етанолу цитодеструктивного ефекту, загальний об'єм та кількість сеансів інтратуморального введення оцтової кислоти втричі менші (Ohnishi, et al., 1996, as cited in Yu, H., \& Burke, 2014; Ohnishi, et al., 1998 as cited in Yu, H., \& Burke, 2014).

Гідроксид натрію належить до лужних розчинів. Експериментальні дослідження гідроксиду натрію на тваринних моделях показали, що його пошкоджуючі властивості залежать від концентрації розчину та менший системний токсичний вплив на організм (Tamai, et al., 2000 as cited in Yu, H., \& Burke, 2014).

Гідроксид натрію застосовують в поєднанні з оцтовою кислотою, в результаті чого відбувається реакція нейтралізації зі значним вивільненням тепла. Дана методика отримала назву термохімічна абляція. Так, Farnam et al. (2010) у своєму дослідженні ex-vivo на моделі печінки свині показав, що поєднання гідроксиду натрію та оцтової кислоти вивільняє значну теплову енергію в місці ін'єкції. Це призводить до виникнення коагуляційного некрозу. При чому збільшення концентрації та об'єму реагентів сприяє підвищенню температур та збільшенню площі терміного ураження (Farnam, et al., 2010). 
Вперше, про результати застосування $10 \%$ розчину кальцію хлориду 3 метою хімічної абляції пухлин печінки повідомили Дронов та ін. в 2013 році (Дронов, та ін. 2013). На основі експериментальних та клінічних досліджень, автори встановили безпечність та ефективність застосування $10 \%$ розчину кальцію хлориду для ПХА злоякісних новоутворень печінки. У основі цитодеструктивної дії даного хімічного агенту лежить здатність викликати виражений некроз біологічних тканин, шляхом дегідратації клітин-мішеней та тромбозу судин мікроциркуляторного русла (Dronov, Kovalska, Kozachuk, et al., 2019; Dronov, Kovalska, et al. 2019).

\section{Методика виконання}

Процедура ПХА передбачає інтратуморальне введення хімічного агенту "real-time" під контролем методів візуалізації (УзД або КТ). Для пункції використовують голку діаметром 23G, яку проводять до найбільш віддаленого полюсу пухлини (Islam, et al., 2012; Thandassery, et al., 2014).

Дозу 95\% етанолу розраховують за формулою:

$$
\mathrm{V}=4 / 3 \pi(\mathrm{r}+0.5)^{3},
$$

де $\mathrm{V}$ - об'єм препарату (мл), $\mathrm{r}$ - максимальний радіус пухлинного вогнища (см), 0,5коефіцієнт корекції для збільшення зони некрозу (Thandassery, et al., 2014).

Максимальна доза алкоголю на один сеанс становить 10 мл і для абляції одного пухлинного вузла не повинна перевищувати 20 мл (Islam, et al., 2012).

Препарат вводять дуже повільно, в різні ділянки новоутворення. Для досягнення бажаного ефекту слід проводити декілька сеанів 1-2 рази на тиждень в залежності від розміру вогнища, інтратуморального накопичення етанолу та загального стану пацієнта. Кількість сеансів від 4-6 (Islam, et al., 2012; Thandassery, et al., 2014).

Під час введення, етанол може витікати в зворотньому напрямку вздовж каналу пункції. Це призводить до виникнення больового синдрому. Тому дану процедуру проводять амбулаторно багаторазово малими дозами під місцевою анестезією або одноразово під загальним знеболенням (Islam, et al., 2012;
Thandassery, et al., 2014).

Методика інтратуморального введення оцтової кислоти подібна до ПІЕ. Однак, доза становить 1,0-2,0 мл на 1 вогнище за 1 сеанс 1 раз на тиждень (Thandassery, et al., 2014).

\section{Показання та протипоказання.}

Перкутанна хімічна абляція - це метод другої лінії і застосовується лише у випадках, наявності протипоказань до виконання радіочастотної абляції. До них відносять: ентеробіліарний рефлюкс, адгезія між пухлиною та шлунково-кишковим трактом тощо (Omata, et al. 2017; Shiina, et al., 2018).

Найбільш оптимальними характеристиками пухлинних вогнищ для проведення ПХА є: солітарне вогнище до 5,0 см в діаметрі або 3 вузла до 3,0 см кожен, м'якої консистенції, 3 щільною сполучнотканинною капсулою, одиничними інтратуморальними перетинками та/ або дочірніми вузлами (Islam, et al., 2012; Yu, H., \& Burke, 2014)

До протипоказань ПХА відносять: множинне (більше 3 вузлів) ураження, важкодоступна для пункції локалізація, наявність тяжкого асциту, коагулопатії, що не піддається корекції (тромбоцитопенія $<40 \times 10^{9} / \mathrm{L}$, ПТІ $<$ $35 \%$ ), жовтяниці (гіпербілірубінемія $\geq 3,0 \mathrm{mg} /$ $\mathrm{dl}$ ), піддіафрагмальна та близька до головних жовчних протоків, печінкових судин, шлунку, кишківника локалізація. Вказані фактори підвищують ризик виникнення внутрішньочеревної кровотечі, жовчного перитоніту та тромбозу портальної вени (Islam, et al., 2012; Shiina, Tateishi, et al., 2012).

\section{Оцінка ефективності}

Оцінка ефективності ПХА передбачає виконання контрастної багатофазної КТ або МРТ, визначення рівнів АФП та печінкових проб (Yu, S. J., et al., 2016).

Основними критерія оцінки локальної відповіді ГЦК на ПХА є критерії EASL (European Association For The Study Of The Liver) та mRECIST (modified Response Evaluation Criteria in Solid Tumors). Дані критерії включають не лише зменшення розміру пухлинного вогнища, а ступінь його некротизації, яка характеризується відсутністю накопичення контрастної речовини в артеріальну фазу (табл. 1) (Vincenzi, et al, 2015). 
Таблиця 1. Радіологічні критерії оцінки ефективності локальної відповіді ГЦК на ПХА (Vincenzi, et al, 2015)

\begin{tabular}{|c|c|c|}
\hline \multirow{2}{*}{ Ступінь відповіді } & \multicolumn{2}{|c|}{ Критерії } \\
\hline & mRECIST & EASL \\
\hline Повна відповідь & $\begin{array}{l}\text { Відсутність контрастного підсилення } \\
\text { в артеріальну фазу в усіх пухлинах- } \\
\text { мішенях }\end{array}$ & $\begin{array}{l}\text { Відсутність будь-яких життєздатних } \\
\text { пухлин-мішеней (контрастне підси- } \\
\text { лення в артеріальну фазу Т1 пост- } \\
\text { контрастну послідовність за даними } \\
\text { МРТ) }\end{array}$ \\
\hline Часткова відповідь & $\begin{array}{l}\geq 30 \text { \% редукції суми діаметрів життє- } \\
\text { здатних вогнищ (контрастне підсилення } \\
\text { в артеріальну фазу) порівняно } 3 \text { почат- } \\
\text { ковою }\end{array}$ & $\begin{array}{l}\geq 50 \text { \% редукції суми діаметрів життє- } \\
\text { здатних вогнищ }\end{array}$ \\
\hline Стабілізація хвороби & $\begin{array}{l}\text { Всі випадки, які не підпадають під } \\
\text { характеристик часткової відповіді або } \\
\text { прогресування хвороби }\end{array}$ & $\begin{array}{l}\text { Всі випадки, які не підпадають під } \\
\text { характеристику часткової відповіді } \\
\text { або прогресування хвороби }\end{array}$ \\
\hline Прогресування хвороби & $\begin{array}{l}\text { Збільшення на } \geq 20 \% \text { суми діаметрів } \\
\text { життєздатних (контрастне підсилення в } \\
\text { артеріальну фазу) пухлин-мішеней, по- } \\
\text { рівняно з найменшою сумою діаметрів } \\
\text { життєздатних (контрастне підсилення } \\
\text { в артеріальну фазу) пухлин до початку } \\
\text { лікування }\end{array}$ & $\begin{array}{l}\text { 3більшення на } \geq 25 \% \text { суми діаметрів } \\
\text { життєздатних пухлин-мішеней }\end{array}$ \\
\hline
\end{tabular}

Відповідно до рекомендацій Interventional Working Group on Image-Guided Tumor Ablation "технічну” ефективність ПХА слід аналізувати на основі даних контрастної КТ/ МРТ в контрольні терміни - безпосередньо після втручання, через 1 тиждень або через 1 місяць (Goldberg, et al., 2005 as cited in Yu, S. J., et al., 2016).

Успішним вважається лікування, при якому протягом 1-місячного спостереження зберігається повна абляція пухлини-мішені. У такому випадку подальше спостереження необхідно проводити кожні 3-4 місяці із застосуванням контрастної багатофазної КТ або МРТ та визначенням рівню АФП у сироватці крові (Goldberg, et al., 2005 as cited in Yu, S. J., et al., 2016).

Незадовільні результати ПХА характеризуються збереженням життєздатних новоутворень або поява нових через 1 місяць після ін'єкції і передбачають застосування мультидисциплінарного підходу для вирішення подальшої тактики лікування (Yu, S. J., et al., 2016).

\section{Специфічні ускладнення}

Найбільш часто $(38,5 \%)$ діагностують такі побічні ефекти ПІЕ, як біль, лихоманка, відчуття алкогольного сп'яніння, підвищення рівня трансаміназ, транзиторна артеріальна гіпертензія (12\%), гіпотензія або nervusvagus синдром (7\%), нудота та блювання (Castroagudin, et al., 2005 as cited in Unzueta, \& Cabrera, 2017; Islam, et al., 2012).

Абдомінальний біль спостерігається у 48\% випадків і як правило локалізується в ділянці пункції. Може іррадіювати в інші ділянки живота або плече. Майже 11-29\% пацієнтів, в залежності від дози препарату, потребують введення анальгетиків.

Лихоманка $\geq 38^{\circ} \mathrm{C}$ спостерігається приблизно у $24 \%$ випадках і пов'язана в першу чергу з об'ємом хімічного некрозу пухлинного вогнища.

Деякі автори пояснюють виникнення болю та лихоманки $з$ рефлюксом етанолу під час екстракції голки, що призводить до подразнення капсули печінки та парієтальної очеревини (Islam, et al., 2012). 
Виникнення тяжких ускладнень спостерігають майже у 3,2\% пацієнтів. До них відносять: внутрішньочеревна кровотеча, сегментарний хімічний тромбоз ворітної вени, правобічний ексудативний плеврит, обструктивна жовтяниця, холангіт, формування печінкових абсцесів, інфаркт печінки, пошкодження жовчного міхура, протоків або порожнистих органів, жовчний перитоніт, біліарна нориця, артеріо-портальний шунт, пневмоторакс та шок (Islam, et al., 2012; Naeem, \& Abid, 2018; Shiina, Tateishi, et al., 2012, Castroagudin, et al., 2005 as cited in Unzueta, \& Cabrera, 2017).

Летальність, пов'язана з ПХА становить 0-0,4\% (Omata, et al. 2017, Shiina, et al., 2018).

Питання ризику пухлинної дисемінації в місці ін'єкції під час інтратуморальної ін'єкції етанолу залишається суперечливим. Так, деякі автори повідомляють,що частота імплантаційного метастазування ГЦК після ПІЕ може досягати 0,13 - 2,2\% (Ahn, 2011; Di Stasi et al., 1997 as cited in Ahn, 2011; Ishii et al., 1998 as cited in Ahn, 2011). Інші дослідники вважають, що цитодеструктивний вплив етанолу на клітини-мішені та тромбоз інтратуморальних судин навпаки запобігають дисемінації пухлинних клітин (Islam, et al., 2012)

Перкутанна ін'єкція оцтової кислоти (ПІОК) - безпечний метод, який рідко супроводжується тяжкими побічними явищами. До ускладнень, що можуть виникати при інтратуморальному введені даного агенту належать: транзиторна гемоглобулінурія без порушення функції нирок, лихоманка, біль в правому підребер'ї, сегментарний інфаркт печінки та метаболічний ацидоз. 3 метою профілактики транзиторної гемоглобулінурії показане внутрішньовенна інфузія бікарбонатних розчинів (Loffroy et al., 2016; Thandassery, et al. 2014)

Результати клінічного застосування ПХА

Ефективність клінічного застосування ПХА безпосередньо залежить від розміру пухлинного вогнища (Shiina, et al., 2018; Thandassery et al., 2014).

Так, інтратуморальне введення етанолу призводить до некротизації 90\% -100\% пухлинних вузлів ГЦК діаметром $\leq 2,0$ см та $70 \%$ при пухлинах 2,0 - 3,0 см (Yu, S. J. et al., 2009).

Частота повної відповіді на ПІЕ пухлинних вогнищ до 3,0 см становить $80 \%$, а при
3,0-5,0 см або багатовузловому уражені - не перевищує 50\%. Прогресування хвороби та локальний рецидив найбільш часто діагностується серед новоутворень більше 3,0 см в діаметрі - 6-31\% та $>40 \%$ відповідно (Shiina, et al., 2018; Thandassery et al., 2014).

За даними італійського рандомізованого дослідження, частота повних відповідей вогнищ діаметром $2,2 \pm 0,5$ см $-100 \%$. Одно-, 3- та 5- річна кумулятивна виживаність серед пацієнтів після ПІЕ вогнищ до 3,0 см складає $95 \%, 78 \%$ та $68 \%$, вогнищ до 2,0 см - 94\%, $79 \%$ та $68 \%$ відповідно. Частота локального рецидивування при ГЦК до 3,0 см спостерігається у $5,2 \%, 9,4 \%$, та $12,8 \%$ через 1,3 та 5 років після ПІЕ відповідно (Giorgio et al., 2011).

У дослідженні Shiina et al. (2012), у яке було включено 685 первинних хворих на ГЦК та проведено 2147 ПІЕ, показав, що 5-, 10- та 20-річна виживаність таких пацієнтів становить $49,0 \%, 17,9 \%$ та 7,2\% відповідно (Shiina et al., 2012)

Діаметр пухлини до 3,0 см також $є$ найбільш оптимальним для застосування ПІОК. Локальний рецидив може виникнути майже у 51 \% пацієнтів впродовж 1 року після абляції $і$ у 74\% впродовж 3 років. Одно- та 3-річна виживаність становить $84 \%$ та 51\% відповідно (Thandassery et al., 2014).

За даними Ma et al. (2012) загальна 1-, 2-, 3-, 4- та 5- річна виживаність пацієнтів після абляції оцтовою кислотою складає 93\%, 82\%, $68 \%, 59 \%$ і 51\% відповідно. Кумулятивна частота рецидивів ГЦК відповідала 24\%, 40\%, $43 \%, 60 \%$ і $62 \%$ через $1,2,3,4$ та 5 років спостереження відповідно (Ma, Liu, J., \& Liu, F, 2012).

Paul et al. (2020) в своєму досліджені показав, що ПІОК призводила до повних відповідей у 75\% випадках. Загальна виживаність через 12 місяців становила $81,6 \%$, а через 30 місяців - 54,4\% (Paul et al, 2020).

\section{Перкутанна ін'скція етанолу vs оцтової кистоти}

Ефективність обох методів ПХА в лікуванні ГЦК до 3,0 см оведена чисельними клінічними дослідженнями. Однак, лише ПІЕ включено в стандарти надання онкологічної допомоги пацієнтам з ГЦК, що пов'язано 3 більш ретельним вивченням даної методики. 
Незважаючи на це, ряд авторів рекомендує ПІОК ГЦК у випадку, коли необхідно зменшити кількість сеансів введення (Thandassery et al., 2014).

При порівнянні ПІЕ та ПІОК Paul et al. (2011) встановлено переваги застосування саме оцтової кислоти. Так, ризик виникнення локального рецидивування в групі ПІОК був значно менший порівняно з ПІЕ - 8\%та 37\% ( $<0.001)$ відповідно. Одно- та 2-річна виживаність в даному дослідженні, в групі ПІОК становила до 100\% та 90\% відповідно, порівняно з ПІЕ - 85\% та 65\% відповідно (Paul et al, 2011). Інше рандомізоване дослідження також показало кращі результати у пацієнтів 3 ГЦК до 3,0 см (n=31 ПІОК та n=29 ПІЕ) після ПІОК. Автори зазначили, що 1- та 2-річна виживаність в групі ПІОК була статистично вищою (100\% та $92 \%)$ в порівнянні з ПІЕ (83\% та 63\%), $\mathrm{p}=0.0017$. (Ohnishi et al., 1998 as cited in Thandassery et al., 2014 )

У Кокранівський огляд 2015 року було включено 3 рандомізованих дослідження 3 порівняння ефективності ПІЕ та ПІОК, у які увійшло 261 пацієнтів з ГЦК. При аналізі двох досліджень (185 учасників), автори не виявили статистично значимої різниці між методами за загальною (HR 1.47; 95\% CI 0.68-3.19) та безрецидивною (HR 1.42; 95\% CI 0.68-2.94) виживаністю. Недостатня кількість пацієнтів, включених у випробування, не дозволила авторам ревю зробити висновки про редукцію відносного ризику на 20\%. Дані щодо тривалості госпіталізації були представлені лише в 1 досліджені. За результатами аналізу в групі ПІЕ кількість ліжко-днів була статистично меншою (в середньому 1,7 (2-3) дні) порівняно з ПІОК (в середньому 2,2 (2-5) дні) (Weis et al., 2015).

\section{Дискусія}

Протягом останніх двох десятиліть ПХА була широко імплементована в клінічну практику як альтернативний метод малоінвазивного лікування ранніх стадій ГЦК на фоні цирозу у первинно неоперабельних пацієнтів або пацієнтів списку очікування на трансплантацію печінки (Yu, H., \& Burke, 2014).

Однак, нерівномірна інфільтрація хімічним агентом пухлинного вогнища, за рахунок на- явності сполучно тканинних перетинок або багатовузлового росту, призводить до неповного некрозу пухлинних вогнищ діаметром більше 2,0 см та передбачає багаторазове проведення процедури (Facciorusso, Serviddio, \& Muscatiello, 2016). Вказані недоліки, призвели, до того, що радіочастотна абляція (РЧА) за своєю ефективністю, в деякій мірі, витіснила ПХА. На сьогодні, РЧА $є$ першою лінією локальної терапії ГЦК у хворих, що мають протипоказання до хірургічного лікування (Singh, et al., 2016). Не зважаючи на це ПХА досі посідає ключове місце в лікуванні ранніх стадій ГЦК на фоні цирозу при наявності протипоказань до виконання РЧА. Порівняно з РЧА ПХА має менший рівень тяжких ускладнень і $є$ більш безпечною, що особливо важливо у пацієнтів з наявністю тяжкої супутньої патології (Singh, et al., 2016).). Дешевизна, простота виконання, відсутність необхідності залучення складної апаратури також належать до переваг ПХА (Facciorusso, Serviddio, \& Muscatiello, 2016).

Крім того, останні послідження показали, поєднання ПХА з іншими методами локальної абляції (РЧА, мікрохвильовою абляцією, трансартеріальною хіміоемболізацією) значно покращує як безпосередні, так і віддалені результати лікування хворих на ГЦК (Naeem, \& Abid, 2018).

\section{Висновки}

Перкутанна хімічна абляція є безпечним та ефективним метод лікування пацієнтів з ГЦК на ранніх стадіях та цирозом печінки. Даний метод слід використовувати у хворих, які не підлягають радикальному хірургічному лікуванню та як альтернатива радіочастотній абляції у випадку наявності протипоказань.

Фінансування. Фінансування наукової роботи та процесу публікації - коштом авторів.

Конфлікт інтересів. Жоден 3 авторів не отримував дослідних грантів, гонорарів доповідача від будь-яких компаній і не $є$ членом комісій.

Згода на публікацію. Всі автори прочитали і схвалили остаточний варіант рукопису. Всі автори дали згоду на публікацію цього рукопису. 


\section{ЛІТЕРАТУРА}

Дронов, О.І., Крючина, Є.А., Козачук, Є.С., Любенко, Д.Л., Бакунець, Ю.П., Бакунець, П.П., \& Добуш, Р.Д. (2013) Патент України на корисну модель UA 78643 U, МПК (2013.01), А61B 17/00. Спосіб лікування вогнищевої патології печінки метастатичного генезу; заявл. 28.09.2012; опубл. 25.03.2012. Бюл. № 6/2013.

Федоренко, З.П., Гулак, Л.О., Михайлович, Ю.Й., Горох, С.Л., Рижов, А.Ю., Сумкіна, О.В., \& Куценко, Л.Б. (2020) Рак в Україні, 2018-2019. Бюлетень Національного канцер-реєстру, 21.

Ahn, D. W., Shim, J. H., Yoon, J. H., Kim, C. Y., Lee, H. S., Kim, Y. T., \& Kim, Y. J. (2011). Treatment and clinical outcome of needle-track seeding from hepatocellular carcinoma. The Korean journal of hepatology, 17(2), 106-112. https://doi.org/10.3350/ kjhep.2011.17.2.106

Akinyemiju, T., Abera, S., Ahmed, M., Alam, N., Alemayohu, M. A., Allen, C., ... \& Ayele, T. A. (2017). The burden of primary liver cancer and underlying etiologies from 1990 to 2015 at the global, regional, and national level: results from the global burden of disease study 2015. JAMA oncology, 3(12), 1683-1691.

Cescon, M., Cucchetti, A., Ravaioli, M., \& Pinna, A. D. (2013). Hepatocellular carcinoma locoregional therapies for patients in the waiting list. Impact on transplantability and recurrence rate. Journal of hepatology, 58(3), 609-618.

Dronov, O. I., Kovalska, I. O., Zemskov, S. V., Kozachuk, Y. S., Bakunets, P. P., \& Zhulkevych, I. V. (2019). Оцінка безпечності внутрішньопечінкового введення $10 \%$ розчину кальцію хлориду у щурів лінії wistar: експериментальне дослідження. Здобутки клінічної і експериментальної медицини, (2), 125-129.

Dronov, O. I., Kovalska, I. O., Kozachuk, Ye. S., \& Bakunets, P. P. (2019). Results of application of chemical destruction in complex treatment of focal hepatic pathology. Klinicheskaia khirurgiia, 86(5), 12-16.

European Association For The Study Of The Liver. (2018). EASL clinical practice guidelines: management of hepatocellular carcinoma. Journal of hepatology, 69(1), 182-236.

Facciorusso, A., Serviddio, G., \& Muscatiello, N. (2016). Local ablative treatments for hepatocellular carcinoma: An updated review. World Journal of Gastrointestinal Pharmacology and Therapeutics, 7(4), 477.

Farnam, J. L., Smith, B. C., Johnson, B. R., Estrada, R., Edelman, T. L., Farah, R., \& Cressman, E. N. (2010). Thermochemical ablation in an ex-vivo porcine liver model using acetic acid and sodium hydroxide: proof of concept. Journal of vascular and interventional radiology : JVIR, 21(10), 1573-1578. https://doi.org/10.1016/j.jvir.2010.06.012

Ferlay, J., Ervik, M., Lam, F., Colombet, M., Mery, L., Piñeros, M., ... \& Bray, F. (2018). Global cancer observatory: cancer today. Lyon, France: International Agency for Research on Cancer

Forner, A. \& Reig, M, \& Bruix, J,. (2018). Hepatocellular carcinoma. The Lancet, 391. 10.1016/S0140-6736(18)30010-2.

Giorgio, A. D. S. A., Di Sarno, A., De Stefano, G., Scognamiglio, U., Farella, N., Mariniello, A., ... \& Giorgio, V. (2011). Percutaneous radiofrequency ablation of hepatocellular carcinoma compared to percutaneous ethanol injection in treatment of cirrhotic patients: an Italian randomized controlled trial. Anticancer research, 31(6), 2291-2295.

Islam, M., Saha, M., Ahsan, M., \& Mashud, G. (2012). Percutaneous ethanol injection for ablation of hepatocellular carcinoma. Bangladesh Medical Journal Khulna, 43(1-2), 12-17. https://doi.org/10.3329/bmjk.v43i1-2.13017

Kuang, M., Lu, M. D., Xie, X. Y., Xu, H. X., Xu, Z. F., Liu, G. J., Yin, X. Y., Huang, J. F., \& Lencioni, R. (2009). Ethanol ablation of hepatocellular carcinoma Up to $5.0 \mathrm{~cm}$ by using a multipronged injection needle with high-dose strategy. Radiology, 253(2), 552-561. https://doi.org/10.1148/radiol.2532082021

Loffroy, R., Estivalet, L., Favelier, S., Pottecher, P., Genson, P. Y., Cercueli, J. P., \& Krausé, D. (2016). Interventional radiology therapies for liver cancer. Hepatoma Res, 2, 1-9.

Ma, H., Liu, J., \& Liu, F. (2012). CT-guided single high-dose percutaneous acetic acid injection for small hepatocellular carcinoma: A long-term follow-up study. European Journal of Radiology, 81(6), 1184-1186.

Naeem, E., \& Abid, S. (2018). Ablative techniques in hepatocellular carcinoma treatment. Hepatoma Res, 4, 18.

Nault, J. C., Sutter, O., Nahon, P., Ganne-Carrié, N., \& Séror, O. (2018). Percutaneous treatment of hepatocellular carcinoma: state of the art and innovations. Journal of hepatology, 68(4), 783-797.

Omata, M., Cheng, A. L., Kokudo, N., Kudo, M., Lee, J. M., Jia, J., ... \& Jafri, W. (2017). Asia-Pacific clinical practice guidelines on the management of hepatocellular carcinoma: a 2017 update. Hepatology international, 11(4), 317-370.

Paul, S. B., Acharya, S. K., Gamanagatti, S. R., Sreenivas, V., Shalimar, S., \& Gulati, M. S. (2020). Acetic acid versus radiofrequency ablation for the treatment of hepatocellular carcinoma: A randomized controlled trial. Diagnostic and Interventional Imaging, 101(2), 101-110.

Paul, S. B., Gamanagatti, S. R., Aneesh, M. K., \& Acharya, S. K. (2011). Percutaneous ablative therapy for hepatocellular carcinoma. Natl Med J India, 24(6), 347-355. 
Shiina, S., Sato, K., Tateishi, R., Shimizu, M., Ohama, H., Hatanaka, T., ... \& Imai, Y. (2018). Percutaneous ablation for hepatocellular carcinoma: comparison of various ablation techniques and surgery. Canadian Journal of Gastroenterology and Hepatology, 2018.

Shiina, S., Tateishi, R., Imamura, M., Teratani, T., Koike, Y., Sato, S., ... \& Omata, M. (2012). Percutaneous ethanol injection for hepatocellular carcinoma: 20-year outcome and prognostic factors. Liver International, 32(9), 1434-1442.

Singh, S., Singh, J., Dugg, P., Sharma, S., Thakur, V., Kaur, K., ... \& Parmar, J. (2016) Role of percutaneous ethanol ablation in malignant liver tumours. Journal of Biomedical Graphics and Computing, 6(1), 43-48

Tan, C. H., Low, S. C. A., \& Thng, C. H. (2011). APASL and AASLD consensus guidelines on imaging diagnosis of hepatocellular carcinoma: a review. International journal of hepatology, 2011.

Thandassery, R. B., Goenka, U., \& Goenka, M. K. (2014). Role of local ablative therapy for hepatocellular carcinoma. Journal of clinical and experimental hepatology, 4(Suppl 3), S104-S111. https://doi.org/10.1016/j.jceh.2014.03.046

Unzueta, A., \& Cabrera, R. (2017). Treatment options in patients awaiting liver transplantation with hepatocellular carcinoma and cholangiocarcinoma. Clinics in Liver Disease, 21(2), 231-251.

Vincenzi, B., Di Maio, M., Silletta, M., D’Onofrio, L., Spoto, C., Piccirillo, M. C., ... \& Russo, A. (2015). Prognostic relevance of objective response according to EASL criteria and mRECIST criteria in hepatocellular carcinoma patients treated with loco-regional therapies: a literature-based meta-analysis. PloS one, 10(7), e0133488.

Weis, S., Franke, A., Berg, T., Mössner, J., Fleig, W. E., \& Schoppmeyer, K. (2015). Percutaneous ethanol injection or percutaneous acetic acid injection for early hepatocellular carcinoma. Cochrane Database of Systematic Reviews, (1).

Yu, H., \& Burke, C. T. (2014, June). Comparison of percutaneous ablation technologies in the treatment of malignant liver tumors. In Seminars in interventional radiology (Vol. 31, No. 2, p. 129). Thieme Medical Publishers.

Yu, S. J., Yoon, J. H., Lee, J. M., Lee, J. Y., Kim, S. H., Cho, Y. Y., Yoo, J. J., Lee, M., Lee, D. H., Cho, Y., Cho, E. J., Lee, J. H., Kim, Y. J., \& Kim, C. Y. (2016). Percutaneous ethanol injection therapy is comparable to radiofrequency ablation in hepatocellular carcinoma smaller than $1.5 \mathrm{~cm}$ : A matched case-control comparative analysis. Medicine, 95(35), e4551. https://doi.org/10.1097/ MD.0000000000004551

Ziemlewicz, T. J., Wells, S. A., Lubner, M. G., Brace, C. L., Lee, F. T., \& Hinshaw, J. L. (2016). Hepatic tumor ablation. Surgical Clinics, 96(2), 315-339. 


\title{
THE PERCUTANEOUS CHEMICAL ABLATION APPLICATION IN THE TREATMENT OF PATIENTS WITH HEPATOCELLULAR CARCINOMA
}

\section{Levchenko Lyudmila}

MD, Postgraduate student of the Department of General Surgery №1, Bogomolets National Medical University, Ukraine

\section{Kozachuk Yelyzaveta}

MD, Assistant of the Department of General Surgery №1, Bogomolets National Medical University Ukraine

\section{Zemskov Sergey}

$\mathrm{MD}, \mathrm{PhD}$, Doctor of Medical Science, Professor of the Department of General Surgery № 1, Bogomolets National Medical University, Ukraine

\begin{abstract}
In the world, the incidence of HCC constantly increases each year. In the period from 1990 to 2015, the rate of newly diagnosed cases of HCC increased by 75\%. In Ukraine in 2018, only $18.0 \%$ of primary patients were gotten special treatment: $4.9 \%$ only by surgery, $2.0 \%$ by combined and complex treatment. Unsatisfactory results of special treatment coverage are associated with the peculiarities of the etiopathogenesis of HCC, asymptomatic course, and improper screening system of patients at risk, which leads to difficulty in diagnosis of HCC in the early stages. The choice of HCC treatment tactics, associated with viral hepatitis and liver cirrhosis, remains a difficult clinical challenge. The radical treatment at an early stage HCC is a cornerstone for improving overall survival. Percutaneous ablation (PA) was developed for inoperable patients with HCC in the early stages and liver cirrhosis. There are radiofrequency ablation, chemical ablation, cryoablation, microwave ablation, etc. The main indications for the local ablation application are very early and early-stage (according to BCLC - stage 0 and A), compensated or subcompensated liver function in cirrhosis (Child-Pugh class $\mathrm{A}$ and B), ECOG 0-1, the diameter of the tumor lesion up to $5.0 \mathrm{~cm}$ (most optimally up to $3.0 \mathrm{~cm}$ ), focal nodal lesion, solitary or multiple lesion. Percutaneous ablation is used as a bridge therapy to local tumor control in patients who undergo the Milan and the UCSFC criteria and are on the waiting list for transplantation. These methods have also shown their effectiveness as neoadjuvant «downstaging» therapy in patients who are not candidates for liver transplantation and/or with initially unresectable lesions. For many decades, percutaneous chemical ablation has been the "gold" standard for minimally invasive treatment of HCC. This method is easy to perform, does not require special equipment, is well tolerated by patients, safe, and cost-effective. The main chemical agents are ethanol and acetic acid. The percutaneous chemical ablation procedure involves intratumoral administration of a chemical agent a real-time under the control of imaging (ultrasound or CT). Chemical ablation is a second-line method and is used only in cases where there are contraindications to radiofrequency ablation. This method is not accompanied by severe specific complications and mortality. The effectiveness of its clinical application directly depends on the size of the tumor. The optimal size of the tumor is not more than $3.0 \mathrm{~cm}$. Intratumoral administration of ethano promotes necrosis of $90 \%-100 \%$ of HCC with a diameter of $\leq 2.0 \mathrm{~cm}$ and $70 \%$ for tumors with $2.0-3.0 \mathrm{~cm}$
\end{abstract}

Keywords: hepatocellular carcinoma, percutaneous tumor ablation, chemical ablation, ethanol, acetic acid. 


\section{ПРИМЕНЕНИЕ ПЕРКУТАННОЙ ХИМИЧЕСКОЙ АБЛЯЦИИ В ЛЕЧЕНИИ ПАЦИЕНТОВ С ГЕПАТОЦЕЛЛЮЛЯРНОЙ КАРЦИНОМОЙ}

\section{Левченко Людмила}

Аспирант кафедры общей хирургии №1, НМУ имени А.А. Богомольца, Украина

\section{Козачук Елизавета}

Ассистент кафедры общей хирургии №1, НМУ имени А.А. Богомольца, Украина

\section{Земсков Сергей}

Д.м.н., профессор кафедры общей хирургии № 1, НМУ имени А.А. Богомольца, Украина

Аннотация. Ежегодно частота выявления ГЦК неуклонно растет. В период с 1990 по 2015 год показатель впервые диагностированных случаев ГЦК увеличился на 75\%. В Украине за 2018 год специальным лечением охвачено лишь 18,0\% первичных больных: только хирургическим лечением - 4,9\%, комбинированным и комплексным лечением - 2,0\%. Неудовлетворительные результаты по охвату специальным лечениям связаны с особенностями этиопатогенеза ГЦК, асимптомным течением и несовершенной системой скрининга пациентов группы риска, что затрудняет диагностику заболевания на ранних стадиях. Выбор тактики лечения ГЦК ассоциированной с вирусным гепатитом и циррозом печени до сих пор остается сложной клинической проблемой, поскольку «применение радикального лечения на ранней стадии является краеугольным камнем для улучшения общей выживаемости таких пациентов. Пациентам с ГЦК на ранних стадиях с циррозом печени, не подлежащих радикальному хирургическому лечению на момент обращения, показано применение методов перкутанной абляции - радиочастотная абляция, химическая абляция, криоабляция, микроволновая абляция и тому подобное. Основными показаниями для применения локальной абляции в лечении ГЦК - очень ранняя и ранняя стадия (по BCLC - стадия 0 и A), компенсированная или субкомпенсированная функция печени при циррозе (Child - Pugh класс A и B), общесоматический статус по ECOG 0-1, диаметр опухолевого очага до 5,0 см (наиболее оптимально до 3,0 см), очаговое узловое поражения, солитарный или множественное поражение. Перкутанную абляцию применяют в качестве «бридж»-терапии с целью локального контроля опухолевого роста у пациентов, отвечающих Миланским критериям, критериям UCSFC и находятся в списке ожидания на трансплантацию. Также данные методы показали свою эффективность как неоадъювантная «downstaging» терапия у больных, которые не отвечают критериям для трансплантации печени и / или первично нерезектабельным поражением. В течение многих десятилетий перкутанная химическая абляция была «золотым» стандартом миниинвазивного лечения ГЦК. Данный метод прост в исполнении, не требует специального оборудования, хорошо переносится пациентами, безопасный и экономически выгодный. Основные химические агенты - этанол и уксусная кислота. Процедура перкутанной химической абляции предусматривает интратуморальне введение химического агента «real-time» под контролем методов визуализации (УЗИ или КТ). Химическая абляция - это метод второй линии и применяется только в случаях, наличия противопоказаний к выполнению радиочастотной абляции. Данный метод не сопровождается тяжелыми специфическими осложнениями и летальностью. Эффективность ее клинического применения напрямую зависит от размера опухолевого очага. Оптимальный размер опухолевого очага составляет не более $3,0 \mathrm{~cm}$. Интратуморальне введение этанола приводит к некротизации $90 \%-100 \%$ опухолевых узлов ГЦК диаметром $\leq 2,0$ см и $70 \%$ при опухолях 2,0 - 3,0 см.

Ключевые слова: гепатоцеллюлярная карцинома, перкутанная абляция опухолей, химическая абляция, этанол, уксусная кислота. 